\title{
When the Big Shots Deviate: On the KAP of Religious Clerics Regarding Prevention of COVID-19 [Letter]
}

This article was published in the following Dove Press journal: Risk Management and Healthcare Policy

\section{Syeda Sakina Zehra (D) Muhammad Asif Khalil Laila Shoukat}

Department of Medicine, Karachi Medical and Dental College, Karachi, Pakistan
Correspondence: Syeda Sakina Zehra Karachi Medical and Dental College, Block M North Nazimabad Town, Karachi, Sindh 74700, Pakistan Tel +923322609216

Email szehra362@gmail.com

\section{Dear editor}

We have read the paper by Asmelash et $\mathrm{al}^{1}$ with great interest. In Pakistan, the religious pundits enjoy a huge following as well, coherent with this fact we would like to share our viewpoint towards the study.

This study was conducted when COVID-19 was peaking around the world, which is during May and June. It is the right time to analyze the Knowledge, Attitude, and Practices (KAP) of populations especially when morbidity and mortality were heightened. Moreover, it can inform decision-makers for the second wave for which large-scale lockdowns and curfew seem especially impossible for developing countries and prevention and control of the virus will largely rely on the KAP of populations.

We suspect that due to the cross-sectional nature of this investigation, there lies a risk of social desirability bias from the side of the participants when they were assessed for their attitude and practices. Hence a longitudinal and task-based approach to assess these qualities could give more reliable results.

This research included 260 married individuals as opposed to 150 single, widowed or separated individuals. Therefore, any responses from the married participants would be dominant over those of the other group's individuals. Due to this, we propose that a stratified random sampling method should be used in this regard to help in relating the responses in a correct balance.

In Pakistan, religious leaders were seen actively taking part in the creation of awareness and instructing the public to follow the government's stay-at-home orders. $^{2}$ In the further battle against COVID-19 a strong coalition should be maintained between governments and other groups of people, especially in nations where they have large following, to smartly and effectively work towards prevention and control of the virus.

The infodemic was likewise rampant in Pakistan. As in Ethiopia, the religious clergy believed that COVID-19 was the wrath of God, in Pakistan, the citizens took COVID-19 as mild flu, religious propaganda, governmental propaganda, a bioweapon or microchip to control humans and the influence of $5 \mathrm{G}$ mobile networks, etc. ${ }^{3}$ The sound prevention and control efforts should also include adequate check and balance of these unattested beliefs and stereotypes. 
The results show a huge margin between the knowledge and practices score. One of the reasons for poor compliance towards prevention and control measures of COVID-19 can also be the inability to practise preventive measures in developing countries due to insufficient resources to maintain hygiene, poor ventilation in homes, congested areas and overcrowding in houses, etc. This fact can interfere with the Pearson Correlation. Hence, we think that health officials and decision-makers should be mindful of these lackings and make action plans accordingly.

The authors rightly mention that sensitization programs be held to overcome the poor knowledge, negative attitudes, and incorrect practices among the public. Additionally, we conclude that effective methodologies for disseminating real science which can reduce fear among the population be devised, and wide-scale testing be done by officials as a solution to these problems at hand.

\section{Disclosure}

The authors report no conflicts of interest in this communication.

\section{References}

1. Asmelash D, Fasil A, Tegegne Y, Akalu TY, Ferede HA, Aynalem GL. Knowledge, attitudes and practices toward prevention and early detection of COVID-19 and associated factors among religious clerics and traditional healers in Gondar Town, Northwest Ethiopia: a Community-Based Study. Risk Manag Healthc Policy. 2020;13:2239-2250. doi:10.2147/RMHP.S277846

2. Farooq S, Haider SI, Sachwani S, Parpio YN. Insight into COVID-19 responses and initiatives from Pakistan. $J$ Coll Physicians Surg Pakistan. 2020;30(1):S50-S52. doi:10.29271/jcpsp.2020.Supp1.S50

3. Rafi MS. Dialogic content analysis of misinformation about COVID-19 on social media in Pakistan. Linguist Lit Rev. 2020;6 (2):1-11.

Dove Medical Press encourages responsible, free and frank academic debate. The content of the Risk Management and Healthcare Policy 'letters to the editor' section does not necessarily represent the views of Dove Medical Press, its officers, agents, employees, related entities or the Risk Management and Healthcare Policy editors. While all reasonable steps have been taken to confirm the content of each letter, Dove Medical Press accepts no liability in respect of the content of any letter, nor is it responsible for the content and accuracy of any letter to the editor.

\section{Publish your work in this journal}

Risk Management and Healthcare Policy is an international, peerreviewed, open access journal focusing on all aspects of public health, policy, and preventative measures to promote good health and improve morbidity and mortality in the population. The journal welcomes submitted papers covering original research, basic science, clinical \& epidemiological studies, reviews and evaluations, guidelines, expert opinion and commentary, case reports and extended reports. The manuscript management system is completely online and includes a very quick and fair peer-review system, which is all easy to use. Visit http://www.dovepress.com/testimonials.php to read real quotes from published authors. 